Instructions for authors, subscriptions and further details:

http://remie.hipatiapress.com

\title{
Lecturers' perceptions on the effectiveness of in-service training programs at a selected public sector organization in Namibia
}

Lucky Pieters ${ }^{1}$, Hileni M. Kapenda ${ }^{2}$

1) International University of Management. Namibia

2) University of Namibia. Namibia

Date of publication: June $15^{\text {th }}, 2017$

Edition period: June 2017-October 2017

To cite this article: Pieters, L., \& Kapenda, H. (2017). Lecturers' perceptions on the effectiveness of in-service training programs at a selected public sector organization in Namibia. Multidisciplinary Journal of Educational Research, 7(2), 156-183. doi: 10.17583/remie.2017.2526

To link this article: http://dx.doi.org/10.17583/remie.2017.2526

The terms and conditions of use are related to the Open Journal System and to Creative Commons Attribution License (CC-BY). 


\section{Lecturers' Perceptions on the Effectiveness of In-service Training Programs at a Selected Public Sector Organization in Namibia}

Lucky Pieters

International University of

Management
Hileni M. Kapenda

University of Namibia

\section{Abstract}

The training programs, irrespective of their scopes and time frames, aim to enrich the skills, knowledge level and attitude of participants so that they eventually enhance organizational performance. The training institution investigated in this study did not have a training evaluation policy at its inception. Hence, the aim of this paper is to report on the lecturers' views on the effectiveness of in-service training at one of the public sector organizations in Namibia. The study adopted a quantitative approach and a total of 27 (11 males and 16 females) academic staff participated in it. The results indicate that the majority of respondents are of the view that the institution does not conduct training need assessments. They also expressed that the in-service training programs provided by the institution do not empower them to become better teachers. It is thus recommended that the institution provides in-service training programs that specifically improve lecturers' pedagogical skills in this regard.

Keywords: lecturers' perceptions, in-service training programs, effectiveness of training, public sector organizations, Namibia 


\section{Percepciones del Profesorado sobre la Eficacia de los Programas de Formación Continua en Organizaciones del Sector Público en Namibia}

Lucky Pieters

International University of

Management
Hileni M. Kapenda

University of Namibia

\section{Resumen}

Los programas de formación, independientemente de sus alcances y plazos, tienen por objeto enriquecer las habilidades, el nivel de conocimiento y la actitud de los participantes para que eventualmente mejoren su desempeño profesional. La institución de formación investigada en este estudio no tenía una política de evaluación de formación en su inicio. Por lo tanto, el objetivo de este documento es informar sobre las opiniones del profesorado sobre la efectividad de la formación en servicio en una de las organizaciones del sector público de Namibia. El estudio adoptó un enfoque cuantitativo en un total de 27 personas (11 hombres y 16 mujeres) del personal académico participante. Los resultados indican que la mayoría de los encuestados opinan que la institución no realiza evaluaciones sobre las necesidades de formación. También expresaron que los programas de formación que ofrece la institución no les permiten ser mejores profesores. Así pues, se recomienda que la institución proporcione programas de capacitación que mejoren específicamente las habilidades pedagógicas del profesorado en este sentido.

Palabras clave: percepción docente, formación continua del profesorado, eficacia de la formación, organizaciones del sector público, Namibia 
7 he training programs, irrespective of their scopes and time frames, aim to enrich the skills, knowledge level and attitude of participants so that they eventually enhance organizational performance. The extent to which this enhancement could be realized is the measure of the effectiveness of any training program (Otero, 1997). The training institution investigated in this study did not have a training evaluation policy and the evaluation of staff performance was based on the following outcomes: successful students' intake and registration, submission of student attendance records, class reports, the number of entries of students in performances and examinations, the presentation and quality level of staffand student performances. The aim of the institution at that point in time was to increase the range of subject genres on offer and to increase the number of students to widen the scope of its programs. Lecturers were encouraged to develop new models of tuition, such as group teaching, that were previously not practiced. In-service training was offered in the adaptation of individual student teaching to group tuition. Currently, as part of its capacity building program, lecturers are enrolled for formal and informal courses at reputable institutions (locally and internationally) to upgrade their knowledge and teaching skills. Despite all these efforts, some lecturers still demonstrate little improvement on their teaching and administration skills (E. Junius, personal communication, May 23, 2013). Hence, the objective of this study was to investigate lecturers' perceptions on the effectiveness of the in-service training programs offered at their institution. To reach this objective, the study follows the following sequence. Firstly, the study presents the literature review followed by methods of the study. Next is the presentation of results followed by the discussions. Lastly are the conclusions and recommendations to strengthen the effectiveness of in-service training at the public sector organizations in Namibia.

\section{Literature Review and Theoretical Framework}

This section presents an over view of the theoretical framework focusing on the Brinkerhoff Evaluation Model and its suitability to this study. The literature review section focuses on the role of training provided to 
employees, advantages of training provided, strategies to facilitate the transfer of training and some factors, which influence transfer of training.

\section{The Brinkerhoff's Evaluation Model}

A number of training evaluation models exist such as: Kirkpatrick's 4 Levels of Training and Evaluation Model, the Warr, Bird, and Rackhams' Content, Input, Reaction and Outcome (CIRO) Model, Anthony Hamlin's 5 Level Training Evaluation Model, Jack Phillip's Return on Investment (ROI) Evaluation Model, Content, Input, Process and Product Evaluation (CIPP) Model. Kirkpatrick's Model, according to Topno (2012), focuses on measuring four kinds of outcomes that should be a result from a highly effective program. The CIRO model ultimate evaluation attempts to assess the impact of training on departmental or organizational performance in terms of overall results (Topno, 2012). According to Ahmad and Din (2009) Hamblin's Five Levels of Evaluation Model attempts to obtain feedback on the effects of a training program, and to assess the value of training in light of that information. Phillip's ROI Evaluation Model, translates the worth of training into monetary value. This model provides trainers a framework to view ROI both from human performance and business outcomes perspectives (Topno, 2012). Stufflebeam's CIPP Model's purpose of evaluation is to provide timely information in a systematic way for decisionmaking and thus to improve the functioning of a program (Topno, 2012).

According to Esposito and Freda (2015), the choice of which the evaluation model uses depend on many factors. Nevertheless, this study adopted the Brinkerhoff six stage evaluation model. Brinkerhoff's training evaluation model is simple; it can be implemented in a short time frame and can produce verifiable evidence of the effect of training or the lack of it. Credit is given in case when the impact is successful and weaknesses are pinpointed in the system, then the feedback is directed to those who can address the problem. This model does not apply complex statistical analysis, but rather highlights factual accounts of the best results the program is capable of achieving (Brinkerhoff, 2005). Thus, the Brinkerhoff model evolved from the Kirkpatrick's model and he added two levels at the beginning of Kirkpatrick's model (Otero, 1997). 


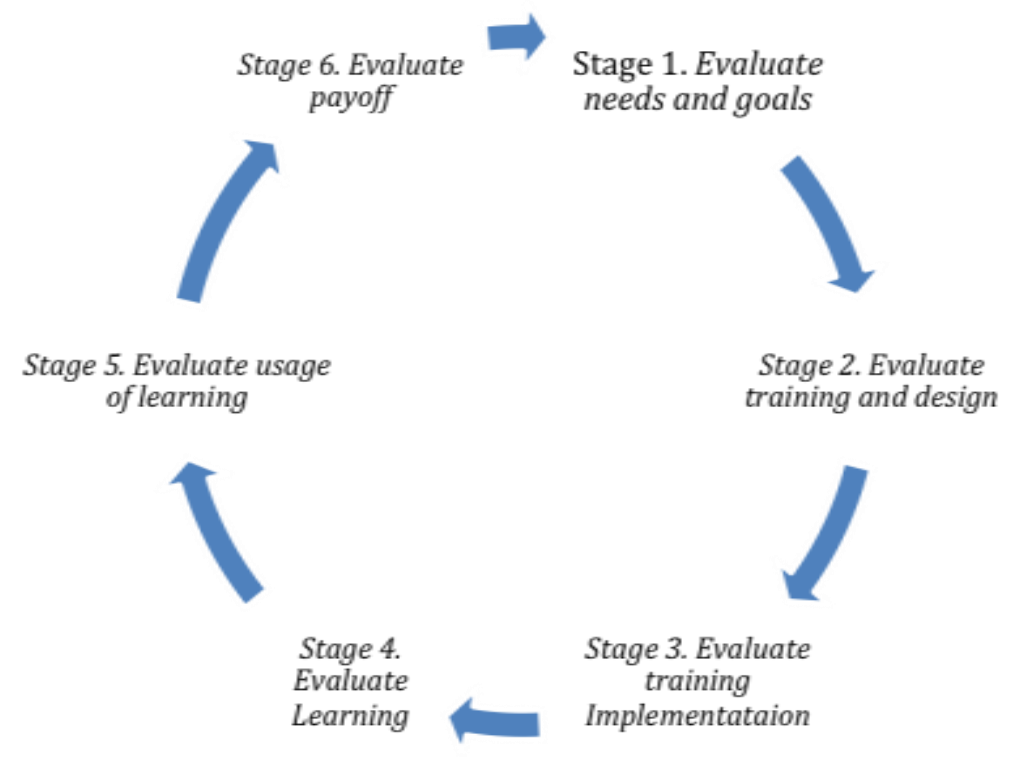

Figure 1. Brinkerhoff's six- Stage Model of Evaluation. Adopted from Otero (1997). Training as a development tool.

The six stages of the Brinkerhoff model borrowed from Otero (1997) are presented and discussed.

Stage 1: Evaluate needs and goals. According to Otero (1997) the data collected at this stage will forecast whether on job behavior should be changed through a training intervention. The data collected at this level is used to evaluate and prioritizes the needs, problems and weaknesses of the organization and establishes the training goals that are worth pursuing. The analysis at this stage provides a skeleton for establishing the value of training and determines its prospective payoffs. This stage is directly linked to the other stages of evaluation and helps to determine whether it was worthy to pursuit the training (Otero, 1997). 
Stage 2: Evaluate training design. Otero (1997) argues that the strength and weakness of each proposed training design is analyzed and the design embodies a combination of the best elements of several designs. The analysis and adequacy of training methods, strategies, materials, trainer, and venues selected is conducted to select the best and appropriate training design. The design should have a clear definition and all stakeholders in the training program must be readily available and clearly understand the various components of the strategy. The training plan adopted and materials selected must also reflect the environment in which training will take place and the demographics composition of participants (Otero, 1997).

Stage 3: Evaluate training implementation. This stage, according to Otero (1997), monitors the training activities and collects comments on the reaction and level of satisfaction of the participants. This stage assesses any inconsistency between what was planned for the training and what is actually taking place. Any training deficiency encountered at this level will require trainers to refer back to the training design in Stage 2 and make alterations. Evaluation techniques at this level include; interviewing participants for more information, selecting trainees who, because of their know-how or leadership qualities, are able to provide thoughtful comments on the training at this stage.

Stage 4: Evaluating learning. This stage determines the level of training and improvements that took place. According to Otero (1997), if adequate learning occurred than one can expect that the training received will be applied at the work place and the planned results should be achieved. The data collected at this stage are used to review and perfect the activities and plans that will ensure the preferred transfer of training. Evaluation at this stage includes gathering evidence that proves that the skill, knowledge and attitude level of participants have improved.

Stage 5: Evaluating the usage of learning. The evaluation at this stage takes place at the workplace (Otero, 1997). Evaluators should take into consideration that actual transfer of training may not take place the way it is 
planned. Evaluation at this stage determines the effective and ineffective ways in which the acquired knowledge, skills and attitude are being applied and suggests the ways of improving the program to achieve the expected transfer of new knowledge, skills and attitude.

Stage 6: Evaluation payoff. Stage 6 assesses the value the changes have brought to the organization and whether this value was worth the effort given and resources committed. The value of the training event is measured by recording the benefits, evaluating their values, and matching them to the training costs. To determine whether the training has paid off, it is imperative to show that evaluation at this stage is linked to stage one (Otero, 1997).

\section{The Suitability of Brinkerhoff's Model to Training Institutions}

The Brinkerhoff model suits the training evaluation process, specifically at the institution investigated in this study. Successful business stories can be compared and contrasted with factors that impede training application (Brinkerhoff, 2005); since the model evaluates the impact of training interventions and communicates the results in a meaningful way to the clients. The Brinkerhoff model is inclusive and focuses on meaningful business results and increases support for performance interventions. The model is simple, can be implemented in a short time frame and produces verifiable evidence of the effect of training or the lack of it. Credit is given in case the impact is successful, weaknesses are pinpointed in the system and feedback directed to those who can address the problem. The model highlights factual accounts of the best results the program is capable of achieving (Brinkerhoff, 2005). Brinkerhoff's model can thus be utilized meaningfully to evaluate and improve training programs.

\section{The Role of Training Provided to Employees}

Training is one of the most prevalent techniques used for enhancing the productivity of individuals and communicating organizational goals to new personnel (Arthur, Bennett, Edens, \& Bell, 2003). The critical role of 
training is to improve human capital performance and ultimately organizational productivity (Obisi, 2011). The common goal of an organization is to grow from strength to strength and training ensures that each employee performs his or her job using the correct techniques and in doing so, helps the organization to achieve its objective (Florence, 2011). Training is a practical and vital necessity because it enables employees to develop and rise within the organization and increases the market value, earning power and job security of an employee. According to Kohlrausch and Rasner (2014, p. 339), "workplace training should be an instrument to make employees feel secure" specifically because "after the school-to-work transition, workplace training is one means for employees to invest in their human capital and their job-specific skills." Therefore, training helps to mold employees' attitude and help them make a meaningful contribution to the organization (Obisi, 2011). McNamara (2013) and Cole (2002) agree that training involves an expert working with participants (students) to transfer skills, behavior and knowledge, to improve the current job.

Training is a learning process which is aimed at impacting behavior, knowledge and skills to enable employees to execute their work tasks better. Khan et al. (2011) argue that training is the most important factor of employee performance and has a distinct role in achievement of organizational goals by incorporating the interest of the organization and the workforce. Training impacts on the return on investment and increases the effectiveness and efficiency of both employees and the organization because of employees who have more work experience, skills, and competencies. According to Coetzer (2006) the implementation of new technology, products or processes, usually requires the acquisition of new knowledge and skills. Therefore, in order to survive, organizations must monitor their external environment and adapt to the changing environment. In light of the above, the view of the authors is that training helps to manage changes in organizational structures caused by mergers, acquisitions, rapid growth, downsizing and outsourcing. These training programs are also important to cope with the changes in technology and with diversity within the organization. 


\section{Advantages of Training Provided to Employees at the Workplace}

Employee training fosters the initiative and creativity of human capital resources and helps to prevent manpower obsolescence, which may be due to age, and the attitude of employees to adapt to technological changes (Obisi, 2011). McNamara (2013) and Cole (2002) agree that training involves an expert working with participants (students) to transfer certain areas of skills, behavior and knowledge, in order to improve the current job. Moreover, Nga et al. (2010) argue that an important component of any effective training is the capacity of trainees to apply the learning gained to their work practice. Effectiveness involves more than improvement of skills and knowledge. In his study on 'the effects of employee empowerment, teamwork, and employee training on organizational commitment' Hanaysha (2016) concluded that employee training has a significant positive effect on organizational commitment; hence training is a useful technique that many organizations use in order to enhance the skills and knowledge of their employees (p. 303). From the studies above, one could thus conclude that training at workplace should be considered as an advantage rather than a burden.

\section{Strategies to Facilitate the Transfer of Training}

According to Nga, Mien, and Wim (2010), transfer of learning during training is not automatically conveyed; therefore the trainees need to have the intention to transfer these skills, knowledge and behavior in a systematic manner, through transfer strategies. These strategies are cognitive and behavioral in nature and include the requirement to set the goals, to analyze the work situation, prepare to deal with difficulties, identifying and use the necessary support, recognize and monitor opportunities to use acquired knowledge and skills on the job (Nga et al., 2010). To maximize the transfer of training, managers, trainees and trainers should be actively involved before, during and after the formal training intervention (Friesen, Kaye, \& Associates [FKA], 2009). The transfer of training that takes place in a continuum of two categories for enhancing learning transfer is now 
discussed: pre-training and transfer strategies during training; and post transfer strategies.

\section{Pre- Training and Transfer Strategies during Training}

Friesen, Kaye, and Associates [FKA] (2009) state that the manager must involve trainees in the training program planning, brief trainees on why they are going for training, and what they should expect from the training and accomplish after the training. Managers should also understand the training course, review expectations, clearly communicate to the staff members that training is a prime organizational goal and must discuss with the trainee how training initiatives will improve the trainee's performance. Similarly, Taylor (1997) argues that it is important for the trainer to involve both supervisors and trainees in the training program as this can help during the needs assessment and course design process. Through this, a program would be tailor made to suit the needs of the organization. In order for training to be effective, the fundamentals of training design will need to be followed. These include selecting the right trainees, matching performance objectives to organizational outcomes, delivering at the right time and choosing the appropriate methods and delivery modes (Allan, 2003). FKA (2009) claim that supervisors must recognize trainee's participation in the training program, communicate supervisory support for the training program and encourage full participation by ensuring that the trainees job content is covered during the training program. Taylor (1997) emphasizes that application - oriented objectives, consisting of behavioral statements of what the trainees should do once they return to their jobs, should be developed. These objectives will prepare trainees to think beyond the training session. FKA (2009) also argue that supervisors must participate in the transfer of training action plans and get feedback, possibly, during each training day from the trainees to ensure the learning program is pertinent and valuable. The supervisor must also plan how he or she will assess the transfer of new skills to the job and prepare for trainees' return to the job (FKA, 2009). 


\section{Post Transfer Strategies}

Allan (2003) argues that transferring skills to the workplace at the conclusion of the training program begins with a post - course debriefing which requires the supervisor to review with the trainees the content of the training program and the experience of trainees' experience. Taylor (1997) stresses the importance of giving a positive reinforcement by systematically applying positive consequences to a trainee, depending on the demonstration of a desired behavior. Positive reinforcement can be highly effective for cementing a pattern of desirable work behavior and stimulate repetition. Richman-Hirsh (2001) argues that post training goals that lead to higher performance should be set. These post training goals direct attention, mobilize effort and encourage persistence on a task. Similarly, Foxon_(1993) argues that the potential of goal setting as a post -training transfer strategy has only being recognized relatively recently and those trainees are more likely to use the training on the job when they are presented with a skill utilization objective, or when they determine their own goals in consultation with the trainer and supervisor. Post transfer goal setting strategies, according to Foxon (1993), increase the likelihood of transfer because they acknowledge the impact of organizational system factors while at the same time assisting the individual to focus on potential applications and to make plans for using the training.

\section{Some Factors which Influence Transfer of Training}

The following factors may influence the success of the transfer of training process:

Employees' attitude and behavior. Mwesigwa (2010) describes an attitude as an internal state of a person that is focused on objects, events, and people and exists in the people's psychological world. Attitude is assessed through one's feelings, thoughts or expressions. Attitude is a perception with a frame of reference. An employee with an attitude that is responsive to training will learn different skills which increase the employee performance and ultimately affect organizational productivity (Khan et al., 2011). An 
employee must also be motivated and willing to learn as that could influence the employee's training and performance outcome (Nga et al., 2010).

Motivation to transfer learning and self-efficacy. Motivation to transfer learning can be described as the trainee's desire to apply the new skills, knowledge and behavior on the job. Trainees' motivation to transfer learning is a key variable in determining the level of transfer of training since a trainee must first be committed to using what he or she has learnt (Nga et al., 2010). Therefore, the higher the motivation and eagerness to transfer the more transfer of learning will take place. According to Yan and Ming (2007) participants are more motivated to learn and transfer their skills to a work environment when they are highly involved in their jobs. Moreover, these authors assert that such participants will transfer skills, knowledge and new behavior, if rewards are associated with training. The self-efficacy of an employee is also an important variable which has an impact on individual and organizational performance. Nga et al. (2010) argue that self-efficacy refers to the confidence of an individual to perform a task. Putting effort into a task is dependent on the belief that an individual can do so. Self-efficacy is positively related to the transfer of learning and has a strong association with motivation to learn and motivation to transfer learning (Nga et al., 2010).

Structural expectations. It is a waste of resources to send participants to a course when they are not keen and motivation to attend. Taylor (1997) suggests that the timing of sending participant for training plays an important role in the learning process. Without the perception by the trainee of the need for new behavior, skills or knowledge; there is no motivation to change and, therefore no readiness to learn. It is therefore imperative that training courses be timed correctly and carefully so that trainees are ready when the training program is offered.

Work environment. A supportive working environment is imperative for any organizational productivity to take place. According to the Society for Human Resource Management [SHRM] (2008) when training is strategically linked to organizational goals, employee will be able to see 
how their training transfer can improve overall organizational performance. An active and supportive organizational climate has to be created at work to make the transfer of training process effective. Employers should encourage a supportive transfer climate, hold trainees accountable for their learning and involve managers and peers to support training transfer and provide trainees with opportunities to practice the new skills in a work setting (SHRM, 2008). This encouragement is important because as concluded by Kohlrausch and Rasner (2014), workplace training has a positive effect on employment outcomes although not all socio-demographic groups might benefit to the same extent.

Commitment of supervisors and staff. According to Hanaysha (2016) organizational commitment reflects loyalty of an employee toward his or her organization and is characterized by a strong belief in and acceptance of the organization's goals and values; willingness to exert considerable effort on behalf the organization and a strong desire to maintain membership of the organization. Haslinda and Mahyuddin (2009) argue that management must ensure that trainees have immediate and frequent opportunities to apply what they have learned in training. Management should encourage and reinforce trainee's application of new skills, knowledge and behavior on the job. They must develop an action plan with trainees and show support by reducing job pressures and workloads, arrange practice sessions, announce transfer of learning successes, give promotional preference to employee who have received training. Staff commitment can be described as staying with the organization through good and bad times; attending work regularly and delivering the best of your ability. Hanaysha (2016) supports this view by arguing that employees who feel committed to their organization reveal higher identification to their values and goals. Favorable behavior outcomes have been associated with employee commitment such as retention, daily attendance, significant achievement, quality of work, and individual sacrifice to help an organization in improving its performance. Redmond (2013) argues that organizational commitment is the degree of an individual's relations and experiences as a sense of loyalty toward one's organization. It involves an individual's willingness to extend effort in order to further an organization's goal. Hence, there is a psychological link 
between an employee and his or her organization that makes it less likely that the employee will voluntarily leave the organization.

Training objectives and human resource policy. Hanaysha (2016) argues that one way to improve the quality of employees is to provide them with beneficial training and development opportunities because the capabilities, knowledge, and skills of the talented employees were proved to be the key determinants of competitive advantage in global marketplaces. Similarly, Algranti (1988) argues that learning alone will not produce the desired employee effectiveness ultimately leading to organizational productivity. The organization should therefore provide training opportunities with end- of course training objectives, on-the-job objectives and end-results objectives that are aligned to the strategic objective of the organization. These objectives are essential to the course design and should not only state what is to be learnt but also how it will be measured. Similarly, Taylor (1997) claims that the best way to influence the transfer of learning is to use it from the learner's point of view and not from the trainer. These objectives enhance the training course and reflect the exact task required by the job. According to Kelana (2010), if a human resource policy is well developed and clearly written, it will enhance communications with employees, clarify expectations, and assist with consistency of application. Haslinda and Mahyuddin (2009) state that a human resources policy should determine a clear link between training opportunities provided and the organization's career development and reward system. Hence, a good human resources policy which is aligned with the strategic objectives of an organization must be implemented at all costs as it will bring greater returns for the organization.

Organizational performance. The effectiveness of training can be evaluated based on some indicators of training. The position of the authors of this paper is that employee performance and organizational performance has a direct relationship. According to Hanaysha (2016) training is associated with the skill that an employee should gain to help him or her by working with others in an attempt to achieve organizational goals and objective. A poorly trained workforce leads to poor performance and costly 
mistakes (Wilke, 2006). Khan et al. (2011) point out that employee performance is the important factor and the building block which increases the overall performance of the organization. Similarly, Cooney, Terziovski and Samson (2002) argue that a firm's performance is enhanced by raising the skills, knowledge and behavior of the employees. As employees become more highly motivated and more highly skilled, so does their task performance and organizational effectiveness. Hence, Hanaysha (2016) confirms that training employees can lead to favorable organizational commitment and job satisfaction.

The main study was based on the effectiveness of training transfer and indicators such as whether lesson delivery plans encouraged the development of critical thinking, problem solving, lesson objectives introduced and clarified at the start of the lesson, just to mention, but a few. Therefore, this paper addressed the lecturers' perceptions on the effectiveness of the in-service training programs offered at this particular public sector organization.

\section{Methodology}

The study adopted a quantitative research method to investigate the effectiveness of in-service training programs at the selected institution in Namibia. The quantitative method focused on numbers or quantities and its results are based on numeric analysis and statistics (Akpo, 2006). Therefore, the study employed a descriptive design. A total of 32 academic staff formed the population as well as the sample of this study. A selfadministered questionnaire was given to all the 32 lecturers. The questionnaire consisted of 23 closed-ended questions of which 6 questions were demographic and 17 quantitative questions. A five Likert scale was used by the participants to indicate the strength of the agreements and disagreements to the items of the questionnaire. 
REMIE - Multidisciplinary Journal of Educational Research, 7(2) 171

\section{Results}

\section{Participants' Biographical Information}

From the 32 questionnaires distributed, only 27 participants (11 males and 16 females) ( $\mathrm{N}=27)$ completed the questionnaires. A high response rate was attributed to the constant appeal and telephone calls made prior to the dispatch of the questionnaires.

Table 1

Level of teaching qualifications of the participants $(N=27)$

\begin{tabular}{lcc}
\hline Teaching qualifications & Frequency & Percent \\
\hline No teaching qualification & 21 & 77.78 \\
Teaching certificate & 2 & 7.41 \\
$\begin{array}{l}\text { Basic Education Teachers } \\
\text { Diploma }\end{array}$ & 0 & 0 \\
Higher Education Diploma & 3 & 11.11 \\
B. Degree in Education & 1 & 3.70 \\
Hon Degree in Education & 0 & 0 \\
Masters in Education & 0 & 0 \\
Total & 27 & 100.0 \\
\hline
\end{tabular}

Table 1 above indicates that the majority of lecturers $(77.78 \%)$ at this College did not have teaching qualifications and therefore are not professional teachers. However, six academic staff have some teaching qualifications including certificates, diplomas and a bachelor degree in education. 


\section{Lecturers' Views on their Training Needs}

The participants' views on their training needs are presented in Figure 2.

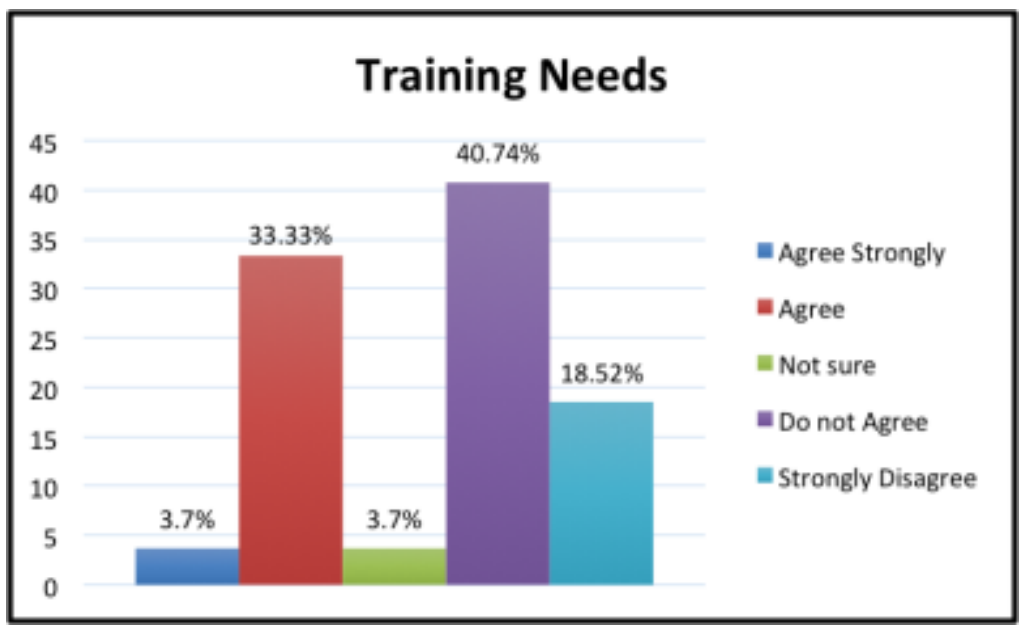

Figure 2. Views on whether the institution conducts training needs analysis

Surprisingly enough, the figure above shows that almost $60 \%$ of the lectures disagreed that the institution conducts training needs analysis exercises; while $37.03 \%$ agreed that the institution does conduct training needs analysis. It can be assumed that the training needs analysis program of this institution is not fully implemented to all staff members. According to Obisi (2011), training should take place only when the need and objectives for such training has been identified. Such training forms the corner stone of sound management, because it makes staff members more effective and productive. On the contrary, the training program at this institution is designed and tailor made for the selected few. The assumption here is that the sense of loyalty of staff members could be affected and such feelings could ultimately negatively influence the performance of the institution. 


\section{Views on the Training Program Objectives}

The participants' views on the training program objectives are presented in Figure 3.

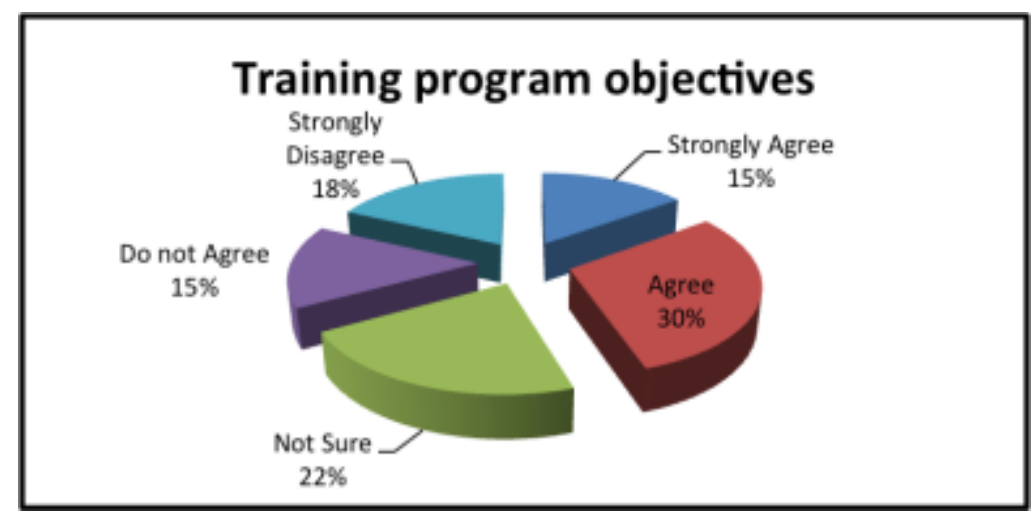

Figure 3. Views on the training program objectives

Figure 3 depicts that $30 \%$ of the respondents agreed that the objectives of the training programs they have attended were fully achieved. These sentiments were supported by $15 \%$ of the respondents who strongly agreed that the objectives of the training programs that they attended were fully achieved. Nevertheless, $15 \%$ of the respondents did not agree that the objectives of the training programs that they attended were fully achieved. Their sentiments were echoed by $18 \%$ of the respondents who strongly disagreed that the objectives of the training programs they have attended were fully achieved. Only $22 \%$ of the respondents were not sure whether the training programs that they attended were fully achieved. The different views of respondents on the training program objectives indicated that there is a lack of clear guidance of what should be expected at the end of their training program. 


\section{Views on the Monitoring of Training Activities Provided to Lecturers}

The views on the monitoring of training activities provided to lecturers are depicted in Figure 4.

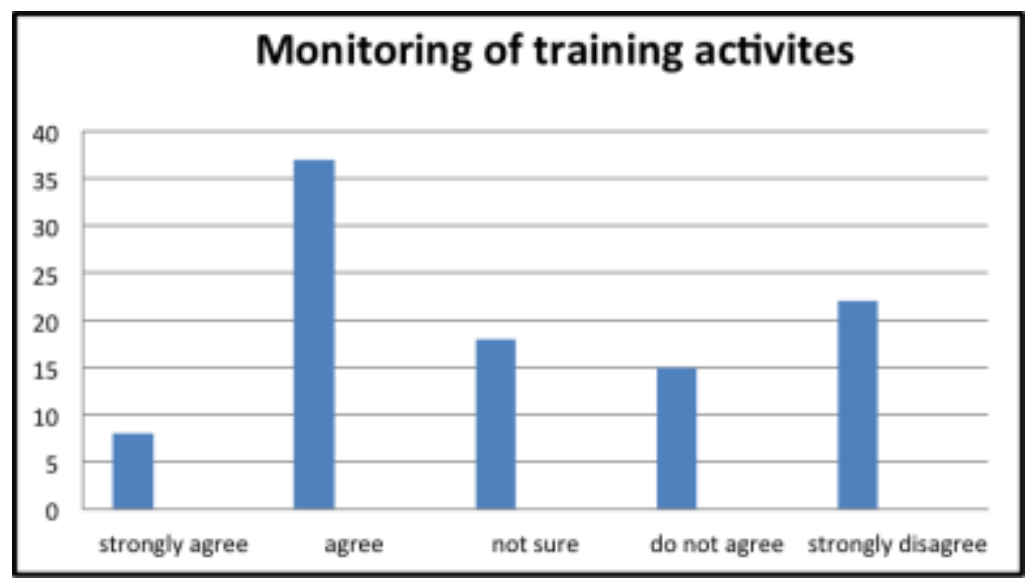

Figure 4. Views on the monitoring of training activities provided to lecturers

Figure 4 shows that $37 \%$ of the respondents agreed that the institution monitors training activities and gathers feedback from participants during training to determine participants' reaction and level of satisfaction. The same sentiments were echoed by $8 \%$ of the respondents who strongly agreed that the institution monitors training activities and gathers feedback from participants during training to determine participants' reaction and level of satisfaction. Still, $15 \%$ of the respondents did not agree that the institution monitors training activities and gathers feedback from participants during training to determine participants' reaction and level of satisfaction. The remaining $22 \%$ strongly disagreed that the institution monitors training activities and gathers feedback from participants during training to determine participants' reaction and level of satisfaction. Only $18 \%$ of the respondents were not sure whether training activities are monitored training 
to determine the lecturers' reaction and level of satisfaction to the training provided.

\section{Lecturers' Views on the Support Rendered for Training Offered}

The lecturers were asked to give their views on the support rendered for training offered as illustrated in Figure 5.

\section{Support for training provided}

Figure 5. Views expressed on support for training provided to lecturers

Figure 5 shows that $37 \%$ of the respondents agreed that training for lecturers receives a high degree of support at all levels at the institution. This was supported by $8 \%$ of the respondents who strongly agreed that the institution supports the training activities for lecturers. On the other hand, $18 \%$ of the respondents were not sure whether training for lecturers received a high degree of support at all levels of their institution. The results indicate that there is a difference of $7 \%$ between the respondents who strongly disagreed and strongly agreed that training received a high degree of support and a further $11 \%$ difference exists between the respondents who agreed and 
those who disagreed that training receive a high degree of support at the institution. It is thus assumed that minimum supervisory support at the institution is taking place; hence staff members will be better motivated if full support is given to implement new knowledge and skills at the workplace.

\section{Views on the Effectiveness of In-service Training Programs}

Figure 6 shows lectures' views on whether the in-service training programs offered at their institution are effective or not.

\section{In-service training programs}

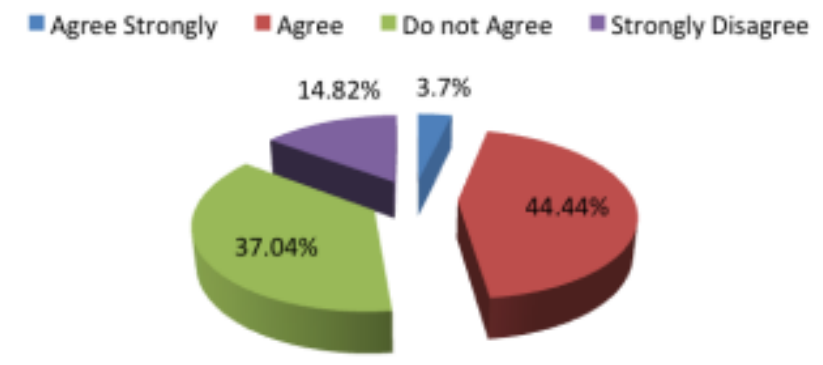

Figure 6. Views on the effectiveness of in-service training programs

On issues of effectiveness of in service training, $44.44 \%$ of the respondents agreed that in-service training programs are effective. This is supported by $3.7 \%$ of the respondents who also strongly agreed that inservice training is effective. However, $37.04 \%$ of the respondents did not agree and they are supported by the remaining $14.82 \%$ of the respondents supported who strongly disagreed that the institution's in-service training is effective. 


\section{Discussion}

The analysis of results in this study revealed mixed findings. For example, Figure 2 indicates that the majority $(60 \%)$ of the participants (compared to $37.03 \%$ ) disagree that the institution conducts training needs analysis exercises. Based on this disparity, the authors concluded that that the training institution need to conduct training needs analysis in order to identify the training needs of the staff and as such identify the organization's weaknesses and strengths. Specifically, Arthur, Bennett, Edens, and Bell (2003, p. 235) state that "a systematic needs assessment can guide and serve as the basis for the design, development, delivery, and evaluation of the training program". Several researchers (e.g., Katman \& Tutkun, 2015; Chimezie \& Osigweh, 1986; Winfrey, 1999) are in support of training needs analysis to assess the effectiveness of training programs.

It is therefore imperative to evaluate the effectiveness of training in order to allow the trainee to know exactly how the learning process brings positive results to the organization. It is thus emphasized that staff members be provided with a clear training program's objectives beforehand. In fact, Algranti (1988), states that learning alone will not produce the desired employee effectiveness, which ultimately lead to organizational productivity. According to Algranti (1988) organization must have lesson objectives; end of course objectives, on-the-job objectives and end-results objectives that are aligned to the strategic objective of the organization. Algranti also emphasized that these objectives are essential as what is to be learnt and how it will be measured are both an important part of the course design. Similarly, Taylor (1997) argues that the formulation of learning objectives by the trainer and not by the learner's point of view inhibit the transfer of learning. The objectives set from the point of view of students could enhance the course content that is offered. Based on the results of Figure 3; it thus suggested that the institution should consider providing an enhanced opportunity to the students in the formulation of training objectives and also in its strategic planning, if the organization wants to develop competent staff members.

Monitoring of training programs is also very important in any organization. Figure 4 indicates scattered opinions on whether the 
institution's monitoring system is effective or not. The monitoring process needs to indicate whether the results have improved and this is an indicator that the training program was effective. If the monitoring process indicates that results were poor or remained the same, then the program needs to be improved. What is important in this context is the supervisory support, because this is believed to be essential in the application of newly acquired knowledge and skills. Therefore, the supervisor must avail opportunities to the trainees to practice. Such opportunities will ensure that the reinforcement of newly acquired knowledge and skills is effective. Supervisors in organizations, according to Allan (2003), must ensure that opportunities are provided to practice the new skills by assigning trainees to the kind of jobs task that will give an opportunity to apply what they have learnt. Hence, monitoring helps to ensure support and coaching provided during workshop could be oriented to play a critical role in assuring the effectiveness in the developmental of employee activities, concerning both training and the application of newly acquired knowledge and skills at the workplace (Nijman \& Gelissen, 2011).

Figure 6 above illustrates mixed responses on the effectiveness of inservice training programs provided to lecturers. This scenario is in contrast to the United States Agency for International Development [USAID] (2011) who argue that in-service training should strive towards greater effectiveness in training outcomes at all levels. It is emphasized that inservice training should lead to efficiency by improving training processes and training modalities, reduce waste and improve cost efficiency. It is therefore of utmost important to ensure that "the effectiveness of the training is determined by the set of goals" (Esposito \& Freda, 2015, p. 78) in any training institution.

\section{Conclusions and Recommendations}

Based on the study findings, it can be concluded that the majority of lecturers who participated in this study are qualified artists and do not possess professional teacher qualifications. These lecturers would therefore find it difficult to effectively transfer knowledge to the students. The lecturers perceived that in-service training courses provided by the 
institution are ineffective and not related to their teaching and methodological skills. In light of the findings reported in this study, it is therefore recommended that the current requirements to become a lecturer at this particular training institution should be amended to include a teaching qualification with at least 3 years teaching experience as a compulsory requirement. The institution should provide in-service training programs that specifically address the improvement of pedagogical skills and should set up a training and performance evaluation committee, which would review the institution's current training and performance evaluation policies and align the policies with the institution's objectives. Consequently, Hanaysha (2016) urges managers and decision makers in higher educational institutions to focus on providing training programs for their employees to ensure that they have enough skills and knowledge to carry out their duties efficiently.

\section{References}

Ahmad, I., \& Din, S. (2009). Evaluating training and development. Gomal Journal of Medical Sciences, 7(2), 165-166. Retrieved from http://gjms.com.pk/files/Review Vol-7-2.pdf

Akpo, S. (2006). Research Methodology [Study guide]. Windhoek:

Polytechnic of Namibia, Centre of Lifelong learning.

Algranti, C. A. (1988). The effects of training on job performance: a study of factors affecting the learning transfer process. (Unpublished Master's thesis). McGill University, Quebec, Montreal.

Allan, L. (2003). Training transfer strategies. Retrieved from

http://www.businessperform.com/workplace-

training/training_transfer.html

Arthur, W. (Jr.)., Bennett, W. (Jr.)., Edens, P., \& Bell, S. T. (2003).

Effectiveness of training in organizations: A meta-analysis of design and evaluation features. Journal of Applied Psychology, 88(2), 234245. doi: 10.1037/0021-9010.88.2.234

Brinkerhoff, R. O. (2005). The success case study method: A strategic evaluation approach to increasing value and effect of training. Advances in Developing Human Resources, 7(1), 86-101. doi: 10.1177/1523422304272172 
180 Pieters \& Kapenda-Lecturers' perceptions of training programs

Chimezie, A. B., \& Osigweh, Yg. (1986). An evaluation model of training outcomes for higher education. Educational Evaluation and Policy Analysis, 8(2), 167-178. doi: 10.3102/01623737008002167

Coetzer, A., J. (2006). Developing human capital in small firms: a conceptual framework for analyzing the effects of managers on employee learning. Research and Practice in Human Resource Management, 14(1), 143-179. Retrieved from http://www.highbeam.com/doc/1G1153309123.html

Cole, G., A. (2002). Personnel Human Resource Management ( $5^{\text {th }}$ Edition). London, UK: Thomson Learning

Cooney, R., Terziovski, M., \& Samson, D. (2002). Employee training, quality management and performance of Australian and New Zealand manufacturers. Working paper series of Monash University, Caulfield East, Australia. Retrieved from https://core.ac.uk/download/pdf/36963919.pdf

Esposito, G., \& Freda, M. F. (2015). Evaluating training context competence of use: productive and unproductive models of use. Evaluation and Program Planning, 50, 77-87. doi:

10.1016/j.evalprogplan.2015.02.003

Florence, T. M. (2011). Multi-skilling at a provincial training institution: Post training evaluation. (Unpublished master' thesis) Cape Peninsula University, South Africa.

Foxon, M. (1993). A process approach to the transfer of training. Australian Journal of Educational Technology, 9(2), 130-143. doi:

10.14742/ajet.2104

Friesen, Kaye, \& Associates (FKA) (2009). Training Transfer: A corporate strategy for applying skills and knowledge in the workplace. Retrieved from http://www.fka.com/files/TrainingTransfer09.pdf

Hanaysha, J. (2016). Examining the effects of employee epowerment, teamwork, and employee traning on organizational commitment. Procedia Social and behavioral Science, 229, 298-306. doi: 10.1016/j.sbspro.2016.07.140

Haslinda, A., \& Mahyuddin, M. Y. (2009). The effectiveness of training in the Public Service [Electronic version]. American Journal of Scientific Research, 6, 39-51. Retrieved from 
REMIE - Multidisciplinary Journal of Educational Research, 7(2) 181

http://www.scribd.com/doc/142513685/The-Effectiveness-of-Trainingin-Public-Service

Katman, A. K., \& Tutkun, O. F. (2015). Teachers' views related to the effectiveness of in-service training programs in primary schools. Procedia-Social and behavioral Sciences, 174, 1878 -1885. doi: 10.1016/j.sbspro.2015.01.851

Kelana, D. (2010). HR policies and the effectiveness of workers' utilization. Retrieved from http://dkelana.wordpress.com/2010/10/26/hr-policiesand-the-effectiveness-of-workers\%e2\% 80\%99-utilisation/

Khan, R. A. G., Khan, A. F., \& Khan, M. A. (2011). Impact of training and development on organizational performance. [Electronic version].Global Journal of Management and Business Research, 11 (7), 62-68. Retrieved from http://globaljournals.org/GJMBR_Volume11/8-Impact-of-Trainingand-Development-on-Organizational-Performance.pdf

Kohlrausch, B., \& Rasner, A. (2014). Workplace training in Germany and its impact on subjective job security: short- or long-term returns? Journal of European Social Policy, 24(4), 337-350. doi:

10.1177/0958928714538216

McNamara, C. (2013). Employee Training and development: Reasons and Benefits. Retrieved from http://managementhelp.org/training/basics/reasons-for-training.htm

Mwesigwa, A. (2010). The impact of training on employee work performance behavior. A case study of government aided secondary schools in Ibanda district, Uganda. (Unpublished master's thesis). International Institute of Social Studies, Hage, Netherlands.

Nga, T. P. P., Mien, S. R. S., Wim., H. G. (2010). Understanding training transfer effects from motivational perspective: A test of MBA Programmes. Business Leadership Review, VII(III), 1-25. Retrieved from https://www.researchgate.net/publication/224841596

Nijman D. J., \& Gelissen, J. (2011). Direct and indirect effects of supervisor support on transfer of training. In Poell, R.F., \& Van Woerkom, M. (Eds.), Supporting workplace learning: towards evidence-based practice (pp. 89-106). Tilburg: Springer Netherlands. doi:

10.1007/978-90-481-9109-3_6 
182 Pieters \& Kapenda-Lecturers' perceptions of training programs

Obisi, C. (2011). Employee Training and Development in Nigerian Organizations. Australian Journal of Business and Management Research, 1(9), 82-264. Retrieved from http://ajbmr.com/articlepdf/AJBMR_16_09i1n9a9.pdf

Otero, C. (1997). Training as a development tool (PN-ACA-630). Washington, DC 20523: Academy for Educational Development. Retrieved from: http://pdf.usaid.gov/pdf_docs/pnaca630.pdf

Redmond, B. F. (2013). Work and Organizational commitment. Pennsylvania State University: The United States of America. Retrieved from https://wikispaces.psu.edu/display/PSYCH484/12+Work+Organization al+Commitment

Richman-Hirsch, W. L. (2001). Post training interventions to enhance transfer: The moderating effects of work environment. Human Resource Development Quarterly, 12(12), 105-120. doi: 10.1002/hrdq.2/abstract Society for Human Resource Management (SHRM) (2008). Transfer of Training. [Power point slides]. Retrieved from http://www.transferoftraining_final.pdf

Taylor, M. (1997). Transfer of learning: Planning workplace education programs. National Literacy Secretariat. Retrieved from http://files.eric.ed.gov/fulltext/ED414462.pdf

Topno, H. (2012). Evaluation of training and development: an analysis of various models. Journal of Business and Management (IOSR-JMB), 5(2) 16-22. Retrieved from http://iosrjournals.org/iosrjbm/papers/Vol5-issue2/B0521622.pdf

United States Agency for International Development (USAID) (2011). USAID policy framework 2011-2015. Retrieved from https://www.usaid.gov/sites/default/files/documents/1870/USAID\%20 Policy\%20Framework\%202011-2015.PDF

Wilke, J. D. (2006). The importance of employee training. Jacksonville Business Journal. Retrieved from www.bizjournal.com/jacksonville/stories/2006/07/24smallb2.html

Winfrey, E.C. (1999). Kirkpatrick's Four Levels of Evaluation. In B. Hoffman (Ed.), Encyclopedia of Educational Technology. Retrieved from http://www.4cleanair.org/Kirkpatrick.pdf 
REMIE - Multidisciplinary Journal of Educational Research, 7(2) 183

Yan, L. C., \& Ming, L. W. (2007, September). An Investigation of employee attitudes towards training effectiveness. International conference on management science and engineering. Retrieved from http://www.seiofbluemountain.com/upload/product/201001/12645799 896xzqyxg.pdf

Lucky Pieters is a Lecturer at the International University of Management.

Hileni M. Kapenda is Director Centre for Research and Publications University of Namibia.

Contact Address: Centre for Research and Publications. Private Bag 13301, 340 Mandume Ndemufayo Ave, Pionierspark, Windhoek, Namibia.

E-mail: hkapenda@unam.na 